\title{
Cloning, Characterization, and Tissue Distribution of Prolactin Receptor in the Sea Bream (Sparus aurata)
}

\author{
C. R. A. Santos, $*$ P. M. Ingleton, $\dagger$ J. E. B. C avaco,* P. A. Kelly, $\ddagger$ \\ M. Edery, $\ddagger$ and D. M. Power* \\ *Centre of Marine Sciences (CCM AR), Universidade do Algarve, Campus de Gambelas, 8000-810 Faro, Portugal; \\ †Institute of Endocrinology, Division of Biochemical and M usculo-skeletal M edicine, M edical School, \\ Sheffield S10 2RX, U nited Kingdom; and ¥F aculté de M edecine N ecker Enfants M alades, \\ IN SERM U nité 344-Endocrinology M oleculaire, 75730 Paris, France
}

Accepted August 15, 2000

The prolactin receptor (PRLR) was cloned and its tissue distribution characterized in adults of the protandrous hermaphrodite marine teleost, the sea bream (Sparus aurata). An homologous CDNA probe for sea bream PRLR (sbPRLR) was obtained by RT-PCR using gill mRNA. This probe was used to screen intestine and kidney CDNA libraries from which two overlapping clones (1100 and 2425 bp, respectively) were obtained. These clones had $100 \%$ sequence identity in the overlapping region ( 893 bp) and were used to deduce the complete amino acid sequence of sbPRLR. The receptor spans $2640 \mathrm{bp}$ and encodes a protein of 537 amino acids. Features characteristic of PRLR, two pairs of cysteines, W S box, hydrophobic transmembrane domain, box 1 , and box 2 , were identified and showed a high degree of sequence identity to PRLRs from other vertebrate species. SbPRLR is 29 and $32 \%$ identical to tilapia (Oreochromis niloticus) and goldfish (Carassius auratus) PRLRs, respectively. In the sea bream two PRLR transcripts of 2.8 and 3.2 kb were detected in the intestine, kidney, and gills and a single transcript of $2.8 \mathrm{~kb}$ was detected in skin and pituitary by Northern blot. Spermiating gonads (more than $95 \%$ male tissue; gonado-somatic index of 0.6 ) contained, in addition to the 2.8-kb transcript, three more transcripts of $1.9,1.3$, and $1.1 \mathrm{~kb}$. RT-PC R, which is a far more sensitive method than Northern blot, detected PRLR mRNA in gills, intestine, brain, pituitary, kidney, liver, gonads, spleen, head-kidney, heart, muscle, and bone. Immuno- histochemistry using specific polyclonal antibodies raised against an oligopeptide from the extracellular domain of sbPRLR detected PRLR in several epithelial tissues of juvenile sea bream, including the anterior gut, renal tubule, choroid membrane of the third ventricle, saccus vasculosus, branchial chloride cells, and branchial cartilage. 02001 Academic Press

Key Words: prolactin receptor; marine teleost; osmoregulation; reproduction.

\section{INTRODUCTION}

Prolactin receptors (PRLRs) belong to an extensive family of hormone and cytokine receptors (class 1 cytokine receptor superfamily), which includes growth hormone $(\mathrm{GH})$ and several interleukin receptors (Finidori and Kelly, 1995). These receptors share several structural features in common: an extracellular domain (ECD) with two pairs of cysteines and a conserved motif (WS box) composed of a conserved amino acid sequence, Trp-Ser-X-Trp-Ser, where $X$ can be any amino acid, a single-transmembrane domain composed largely of hydrophobic amino acids, and an intracellular domain (ICD). The latter domain contains a proline-rich region (box 1), lying immediately adjacent to the membrane, which is composed largely of negatively charged residues and is followed by an- 
other consensus region (box 2), comprising a series of hydrophobic residues followed by negatively charged residues (Bole-Feysot et al., 1998; Kelly et al., 1993, 1991b). These two highly conserved motifs are essential for receptor activity (Goupille et al., 1997).

A PRLR cDNA was first cloned from rat liver (Boutin et al., 1988) and shown to encode a protein of 291 amino acid residues; subsequently, a longer form (591 aa) of the receptor was identified in rat liver and ovary. PRLR cDNAs have now been cloned from species in all vertebrate groups except reptiles (for review see Bole-Feysot et al., 1998). Short and long forms of the PRLR have been identified in rat, mouse, and sheep (Davis and Linzer, 1989; Moore and Oka, 1993; Bignon et al., 1997). These two receptors differ only in the ICD, which is 357 amino acids in the long form and 57 amino acids in the short form which lacks box 2 (Shirota et al., 1990; Bole-Feysot et al., 1998). A third form of PRLR has also been identified in the rat PRLdependent immune cell line ( $\mathrm{Nb2})$; this form contains a partial deletion of the cytoplasmic domain (Ali et al., 1991). Short and long forms of PRLRs originate from alternative splicing of the mRNA transcribed from a single gene (Ormandy et al., 1998) and only long forms are capable of inducing the transcription of milk proteins, whereas short forms are capable of inducing cell proliferation (Das and Vonderhaar, 1995). A single form of PRLR has been identified in birds, which most closely resembles the long form found in mammals, with the exception of a tandem repeat within the ECD (Chen and Horseman, 1994; Zhou et al., 1996). In tetrapods, PRLR has a widespread distribution and has been identified in brain and pituitary, liver, kidney, lungs, skin, gonads and accessory glands, skeletal muscle, and tissues of the immune system (for review Bole-Feysot et al., 1998); it has also recently been detected in bone (Clement-Lacroix et al., 1999).

PRLRs have also been cloned in an amphibian (Yamamoto et al., 1998), in a euryhaline teleost, Nile tilapia (Oreochromis niloticus) (tiPRLR) (Sandra et al., 1995), and in a fresh water teleost, the goldfish (Carassius auratus) (gf PRLR) (Tse et al., 2000). In tilapia there is a single transcript of $3.2 \mathrm{~kb}$ which shares greatest similarity with the long forms of mammalian PRLRs, although the overall homology is low (37\%) (Sandra et al., 1995, 2000). In the goldfish two transcripts, of 3.5 and $4.6 \mathrm{~kb}$, were identified. The $4.6-\mathrm{kb}$ transcript encodes a 600 -amino acid protein $48.3 \%$ identical to tiPRLR (Tse et al., 2000). The expression of PRLR was analyzed in tilapia by Northern blot and the results obtained demonstrated that the osmoregulatory organs, gills, kidney, and intestine expressed PRLR at higher levels. The ovary, testis, and headkidney (which has hematopoietic function in fish) also expressed PRLR but at much lower levels (Sandra et al., 1995, 2000). A similar distribution of PRLR was also observed in the goldfish (Tse et al., 2000). These results confirmed the results obtained with homologous ligand binding studies in the gills and kidney of tilapia (Auperin et al., 1994) and identified alternative target tissues for PRL in fish. The high levels of PRLR expression in osmoregulatory tissues of fish corroborate the well-documented action of PRL in the maintenance of hydromineral balance in euryhaline teleosts (Bern, 1975).

The function of PRL in marine teleosts is unclear, particularly since in euryhaline fish its principal role appears to be in freshwater adaptation and it inhibits seawater adaptation. High levels of expression of PRL have been reported in the sea bream pituitary gland (Santos et al., 1999) but relatively little is known about its physiological role in marine fish. In the present study the cloning of PRLR cDNA from a marine teleost, the sea bream (Sparus aurata), is described and its expression and tissue localization in adult fish is characterized. In addition, part of the sbPRLR gene was cloned and compared with the gene for mouse PRLR.

\section{MATERIALS AND METHODS}

\section{Animals and Tissues}

Adult sea bream ( $\sim 350 \mathrm{~g})$ maintained in throughflow seawater tanks at $17 \pm 2^{\circ}$ under natural photoperiod for winter in the Algarve, Portugal were killed by stunning and decapitation. Liver, kidney, intestine, brain, pituitary, skin, gills, skeletal muscle, heart, bone, spleen, head-kidney, and mature gonadal tissue (more than 95\% male tissue; gonado-somatic index of $0.6)$ were frozen in liquid nitrogen and stored at $-70^{\circ}$.

\section{Total RNA and mRNA Purification}

Total RNA was extracted from the tissues mentioned above using "TRI reagent" (Sigma, St. Louis, 
$\mathrm{MO})$. The poly $(\mathrm{A})^{+}$RNA fraction was obtained from total RNA by chromatography on columns of oligo(dT) cellulose (Aviv and Leder, 1972).

\section{Generation of a Homologous sbPRLR CDNA Probe by RT-PCR}

PCR primers were designed within the most highly conserved regions of PRLRs identified after multiple sequence alignments of all PRLR sequences available (GenBank). A forward primer based on a highly conserved region of the ECD domain of PRLR (TFTCWW), 5' ACA TTC ACC TGC TGG TGG3' (Pharmacia Biotech, Uppsala, Sweden) (primer PF1), was synthesized and the reverse primer, in which inosine (I) was introduced to minimize degeneracy at the 3' end 5' GAT CTT TGG CAC IGG IGG3' (primer PR1), was located within the proline-rich motif (PPVPGPKI).

cDNA was synthesized from $1 \mu \mathrm{g}$ of gill RNA poly $(\mathrm{A})^{+}$in a $30-\mu 1$ reaction containing $50 \mathrm{mM}$ Tris$\mathrm{HCl}, \mathrm{pH} 8.3,75 \mathrm{mM} \mathrm{KCl}, 3 \mathrm{mM} \mathrm{MgCl}, 10 \mathrm{mM}$ dithiothreitol (DTT), $1 \mathrm{mM}$ dNTP, 15 pmol oligo(dT) primer, RNase inhibitor (3.2 U; Pharmacia Biotech), and MMLV reverse transcriptase (20 U; Gibco BRL, Barcelona), for $2 \mathrm{~h}$ at $37^{\circ}$. PCR was carried out in a 50- $\mu \mathrm{l}$ reaction containing $5 \mu \mathrm{l}$ of gill cDNA, $10 \mathrm{mM}$ Tris$\mathrm{HCl}, \mathrm{pH}$ 9.0, $50 \mathrm{mM} \mathrm{KCl}, 0.1 \%$ Triton X-100, $3 \mathrm{mM}$ $\mathrm{MgCl}_{2}, 1 \mathrm{mM}$ dNTP, 40 pmol of forward primer, 200 pmol of reverse primer, and Taq DNA polymerase (1.25 U; Promega, Madison, WI); sterile water substituted for cDNA in control reactions.

The reaction was initially denatured for $5 \mathrm{~min}$ and then submitted to 45 cycles of denaturing $\left(94^{\circ}, 1 \mathrm{~min}\right)$, annealing $\left(52^{\circ}, 2 \mathrm{~min}\right)$, and extension $\left(72^{\circ}, 1 \mathrm{~min}\right)$ in a thermocycler (Robocycler; Stratagene, La Jolla, CA). The amplified products were analyzed on a $1.5 \%$ agarose gel containing ethidium bromide $(0.5 \mu \mathrm{g} / \mu \mathrm{l})$, excised from the gel, and purified using a column containing a silica-gel membrane (Quiagen).

The purified DNAs were ligated into pGEM-T vector (Promega) in a $10-\mu$ l reaction containing purified DNA $(7 \mu \mathrm{l}), 1 \mu \mathrm{l}$ of T4 DNA ligase $(3 \mathrm{U} / \mathrm{ml}), 1 \mu \mathrm{l}$ of pGEM-T (50 ng), and $1 \mu \mathrm{l}$ of $10 \times$ buffer $(300 \mathrm{mM}$ Tris- $\mathrm{HCl}, \mathrm{pH}$ 7.8, $100 \mathrm{mM} \mathrm{MgCl}$, $100 \mathrm{mM}$ DTT, and $10 \mathrm{mM} \mathrm{ATP})$, incubated overnight at $4^{\circ}$, and used to transform Escherichia coli (XL1B MRF' strain). DNA was isolated from clones and analyzed in $1.5 \%$ agarose gels after restriction digest. Sequencing was carried out using a modification of the dideoxy chain termination method (Sanger et al., 1977; T7 sequencing Kit; Pharmacia Biotech).

\section{Construction of Sea Bream Intestine and Kidney CDNA Libraries}

cDNA libraries were constructed from $5 \mu \mathrm{g}$ of sea bream intestine and kidney poly $(\mathrm{A})^{+}$RNA using the Lambda ZAP cDNA and UNI-ZAP XR cDNA cloning kits (Stratagene), respectively. The double-stranded cDNA was ligated into the corresponding vectors and packaged into Gigapack Gold III packaging extracts (Stratagene).

\section{Screening of CDNA Libraries}

The sea bream intestine library was screened with a $\left[\alpha-{ }^{32} \mathrm{P}\right] \mathrm{dCTP}-\mathrm{labeled}$ sbPRLR probe (Rediprime, random labeling kit; Amersham, Little Chalfont, UK) generated by RT-PCR. Filters were hybridized overnight at $65^{\circ}$ and washed at $65^{\circ}$ in $0.1 \times$ SSC $/ 0.1 \%$ SDS. Two positive plaques were obtained from 400,000 recombinants, isolated, automatically excised into pBluescript (Stratagene), and sequenced using an adaptation of the dideoxy chain termination method (Sanger et al., 1977) with the universal primers within the flanking regions of the polylinker of pBluescript. This clone, named I3a2.2, was then used to screen the kidney cDNA library, and one positive plaque was isolated from 400,000 recombinants. This clone, named KA13.1, was also sequenced from the $3^{\prime}$ and $5^{\prime}$ ends using internal walking primers designed from the newly achieved sequence (Fig. 1).

\section{Northern Blot Analysis}

Two micrograms of mRNA from sea bream liver, kidney, intestine, brain, pituitary, skin, gill, head-kidney, spleen, and skeletal muscle and $10 \mu \mathrm{g}$ of gonad mRNA were fractionated on a 5.5\% formaldehyde/ $1.5 \%$ agarose gel, transferred to a nylon filter (Hybond-N; Amersham) with $10 \times$ SSC, and cross-linked at $80^{\circ}$ for $2 \mathrm{~h}$. Prior to hybridization the filter was washed at $60^{\circ}$ for $20 \mathrm{~min}$ in $1 \times$ SSC, $0.1 \%$ SDS and prehybridized in $50 \%$ formamide, $50 \mathrm{mM} \mathrm{NaPO}_{4}, 5 \times$ Denharts, $0.1 \%$ SDS, $5 \times$ SSC, $50 \mu \mathrm{g} / \mathrm{ml}$ DNA from calf 
thymus for $4 \mathrm{~h}$ at $42^{\circ}$. Hybridization was allowed to proceed overnight at $42^{\circ}$ in fresh prehybridization solution containing sbPRLR clone I3A2.2 labeled with $\left[\alpha-{ }^{32} \mathrm{P}\right] \mathrm{dCTP}$. Filters were then washed for $30 \mathrm{~min}$ at $42^{\circ}$ in prehybridization solution and stringency washes carried out at $55^{\circ}$ for $15 \mathrm{~min}$ in $1 \times$ SSC, $0.1 \%$ SDS and then at $60^{\circ}$ for $30 \mathrm{~min}$. The membrane was exposed to Biomax MS film (Kodak, Rochester, NY) with intensifying screens at $-70^{\circ}$ for 5 days. To evaluate the relative amounts of mRNA for each tissue, the blot was stripped with a boiling solution of $0.1 \%$ SDS and hybridized with a sea bream $\beta$-actin probe (Santos et al., 1997) following the same protocol as before but reducing exposure time to $1 \mathrm{~h}$.

\section{Tissue D istribution by RT -PCR}

The tissue expression of sbPRLR was also analyzed with the more sensitive method of RT-PCR. Specific primers were designed using the Primer Premier computer program (Version 4.04; Premier Biosoft International) based on the sbPRLR sequence. Forward primer (PF2) (5'AGTCCGGCTGGGTCACCATTA) and reverse primer (PR2) (5'GGTGGCGACCAAGATCCAAAAC3') were synthesized by MWG-Biotech $\mathrm{GmbH}$ (Germany) and were predicted to amplify a fragment of $249 \mathrm{bp}$.

cDNA was synthesized in a $30-\mu 1$ reaction as previously described from total RNA $(0.5 \mu \mathrm{g})$ from the following tissue samples: liver, kidney, intestine, brain, pituitary, skin, gills, heart, skeletal muscle, bone, ovary, and testis. As a negative control, a PCR which contained all the reagents, but in which cDNA was omitted, was run simultaneously. RT-PCR was carried out with this cDNA $(5 \mu \mathrm{l})$ in a $50-\mu$ l reaction as previously described, with the exception that a lower concentration of $\mathrm{MgCl}_{2}(1.5 \mathrm{mM}), 50$ pmol of each primer, and Taq DNA polymerase (1.25 U; Promega) were used. The thermocycling protocol (Robocycler; Stratagene) was as follows: initial denaturing step $\left(94^{\circ}, 2 \mathrm{~min}\right)$ followed by 35 cycles of denaturation $\left(94^{\circ}\right.$, $1 \mathrm{~min})$, annealing $\left(56^{\circ}, 1 \mathrm{~min}\right)$, and extension $\left(72^{\circ}\right.$, $30 \mathrm{~s})$.

\section{Southern Blot Analysis}

PCR products were separated on a TBE/agarose gel (1.5\%). The gel was soaked in denaturing solution (0.5
$\mathrm{M} \mathrm{NaOH}, 1.5 \mathrm{M} \mathrm{NaCl}$ ) for 15 min with gentle agitation, washed twice for $2 \mathrm{~min}$ in sterile water, and soaked in neutralizing solution $(1.5 \mathrm{M} \mathrm{NaCl}, 0.5 \mathrm{M}$ Tris- $\mathrm{HCl}, \mathrm{pH}$ 8.0) for $30 \mathrm{~min}$. Transfer to a nitrocellulose membrane (Hybond C; Amersham) was carried out using $10 \times$ SSC as transfer buffer. The membrane was baked for $2 \mathrm{~h}$ at $80^{\circ}$ and hybridized using sbPRLR clone I3A2.2 as the probe and the same procedure described for cDNA library screening. The blot was exposed for $5 \mathrm{~min}$ and $2 \mathrm{~h}$ at room temperature $\left(24^{\circ}\right)$.

\section{Partial Cloning of sbPRLR Gene}

Genomic DNA was extracted using TRI reagent (Sigma). The PCR protocol already described above for analyzing sbPRLR expression in adult tissue was applied to approximately $10 \mathrm{ng}$ of sea bream genomic DNA using primers PF2 and PR2. The product obtained was cloned into pGEM-T vector using the protocol already described for cloning the sbPRLR probe and its sequence was determined.

\section{Tissue D istribution by Immunohistochemistry (IHC)}

The methodology used for antibody production is detailed in Nevalainen et al. (1996). Briefly, an oligopeptide from the extracellular domain of sbPRLR was synthesized by Sheffield University Krebs Institute Molecular Synthesis Service using Applied Biosystems Model 476A. The chosen sequence, 35-49 (RLYYERERLEGVHEC) from the extracellular domain of the sbPRLR, was conjugated to bovine thyroglobulin (Sigma T-1001) using carbodiimide. The oligopeptide was chosen on the basis of amino acid composition and because a similar region of rat prolactin receptor has been found to induce high-quality antisera used for detecting PRLR in many mammalian tissues. The conjugate was dissolved in normal saline, emulsified in Freund's Complete Adjuvant, and injected intramuscularly into rabbits. A second injection of antigen, emulsified in Freund's Incomplete Adjuvant, was given 2 months later, and after an initial test bleed the serum was collected 14 days after the second injection.

Immunohistochemistry was carried out using a modification of Sternberger (1974). Briefly, tissues were fixed in sublimated Bouin-Hollande (Kraicer et al., 1967). Sections were cut at $4 \mu \mathrm{m}$ and mounted on APES-coated slides. For IHC, sections were dewaxed 
in xylene and rehydrated in graded alcohols, and heavy metal ions were removed by immersion in 1\% iodine in $70 \%$ ethanol and reduced in 5\% sodium thiosulphate. For the IHC procedure, sections were immersed first in $1 \%$ hydrogen peroxide in phosphate buffer (100 mM, pH 7.4) containing 20\% methanol to destroy endogenous peroxidase; then nonspecific binding sites were blocked using $4 \%$ swine serum in $1 \%$ bovine serum albumin (BSA) in phosphate buffer. Sections were then covered in the primary rabbit antiserum to sea bream PRLRs diluted in phosphatebuffered saline (PBS) /BSA $(1 / 200)$ and incubated at $4^{\circ}$ overnight; control slides received normal rabbit serum instead of specific primary antiserum. After washing, the sections were incubated at room temperature (ca. $20^{\circ}$ ) in swine anti-rabbit serum diluted 1/50 (Dako, Denmark) and then in peroxidase/anti-peroxidase reagent (Dako). Color was generated by immersion in diaminobenzidine in Tris- $\mathrm{HCl}$ buffer, $\mathrm{pH}$ 7.6. Sections were dehydrated, cleared, and mounted in Depex. Cross-reaction to bovine thyroglobulin was checked by absorption of diluted antiserum with $500 \mu \mathrm{g} / \mathrm{ml}$ of bovine thyroglobulin and testing on sections of larvae containing thyroid follicles.

\section{RESULTS}

\section{sbPRLR Probe}

A cDNA fragment spanning 429 bp was obtained by RT-PCR using primers PF1 and PR1. The sequence of this fragment was compared to sequences available in the EMBL databases (NCBI, BLASTX) and was found to have the highest homology with tiPRLR (43\% identity). The sea bream RT-PCR product was found to align with tiPRLR in the region predicted from primer localization and consisted of part of the ECD and part of the ICD. The PCR product was of a smaller size than predicted as the forward primer annealed downstream to the region for which it was designed. In addition to the overall sequence similarity to tiPRLR, other structural features characteristic of PRLR were also present in this fragment, such as the WS box (WSEWT) and a 24amino acid transmembrane domain with a high content of hydrophobic amino acids.

\section{NA Library Screening}

The RT-PCR product was used as a probe to screen a sea bream intestine cDNA library containing 450,000 primary recombinants. Two clones were isolated from 400,000 recombinants; the clone inserts were excised and sized by agarose gel electrophoresis, where they were observed to be of a similar size (1100 bp). Sequencing revealed that one insert was $23 \mathrm{bp}$ longer at the $5^{\prime}$ end (clone I3A2.2). Both inserts shared 100\% identity in the overlap. The deduced amino acid sequence showed that they encoded the complete ECD, the transmembrane domain, and part of the cytoplasmic domain (Fig. 1). The longer clone (I3A2.2) was then used to screen the sea bream kidney cDNA library $\left(2 \times 10^{6}\right.$ primary recombinants $)$ from which another clone, 2425-bp long, was isolated from 400,000 recombinants. This clone was incomplete at the $5^{\prime}$ end. Alignment of the sequences of the clones obtained from the intestine and kidney libraries showed that both were $100 \%$ identical in the overlap (893 bp) and, in combination, permitted elucidation of the fulllength sequence of sbPRLR.

SbPRLR spans $2.6 \mathrm{~kb}$ and contains an open reading frame (ORF) encoding a protein of 537 amino acids (Fig. 1). This ORF consists of a signal peptide of 20 amino acids followed by a mature protein of 517 amino acids. The $5^{\prime}$ untranslated region (UTR) com-

\footnotetext{
FIG. 1. Nucleotide sequence and deduced amino acid sequence of the sea bream PRLR. The sequence underlined comprises the overlapping region between clones I3A.2.2. and KA13.1. The cysteine residues are circled; the four potential N-glycosylation sites are enclosed by pentagons. The WS motif is boxed and the transmembrane domain is in italics. Within the intracellular domain, box 1 (next to the transmembrane domain) and box 2 are boxed. Single tyrosine residues are enclosed by a star. In the $3^{\prime}$ untranslated region three potential polyadenylation signals are printed in boldface and underlined. Nucleotide sequences printed in boldface correspond to the primers used to analyze tissue distribution by RT-PCR. Walking primers used to elucidate the complete nucleotide sequence of sbPRLR are enclosed by an arrow.
} 
$-120$

$-21$

$-40$

$-11$

350

1111

370

1171

390

1231

410

1291

430

1351

450

1411

470

1471 490

1531

510

1591

1662

1742

1822

1902

1982

2062

2142

2222

2302

2382

2462 cgttcacgacaatgttgtggccgtaggaggcttctgttcgcaacatggagttcagtgactcagtcgtgtaggtcgacact cgtcctcagctggacacactgcgggacagttggcgccagg ATG TGG AGA GAT CTT GGA TTG GCA GTT CTT $\begin{array}{cccccccccccccccccccc}\text { V } & \text { L } & \text { L } & \text { S } & \text { A } & \text { A } & V & \text { E } & S & N & S & T & S & P & P & G & K & \text { P } & V & L \\ \text { GTG } & \text { CTG } & \text { CTG } & \text { TCT } & \text { GCA } & \text { GCT } & \text { GTA } & \text { GAG } & \text { TCC } & \text { AAC } & \text { AGC } & \text { ACG } & \text { TCT } & \text { CCA } & \text { CCA } & \text { GGG } & \text { AAA } & \text { CCG } & \text { GTC } & \text { CTG }\end{array}$

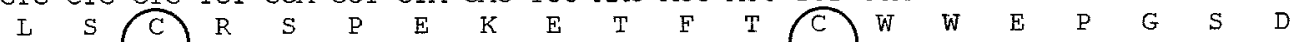
CTC AGC TGC AGG TCC CCT GAG AAG GAG ACG TTT ACC TGC TGG TGG GAG CCA GGC TCT GAT

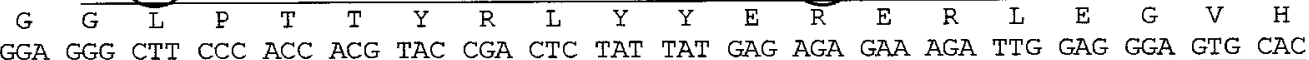

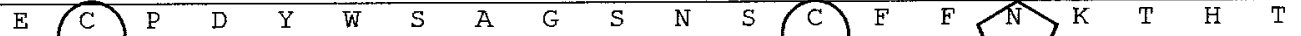
GAG (TGT CCG GAC TAT TGG TCA GCA GGT AGC AAC TCC TTGT TTC TTC AAC AAG ACC CAC ACC $\begin{array}{llllllllllllllllllllll}L & I & W & V & D & Y & Y & I & T & V & V & A & S & N & A & L & G & A & T\end{array}$

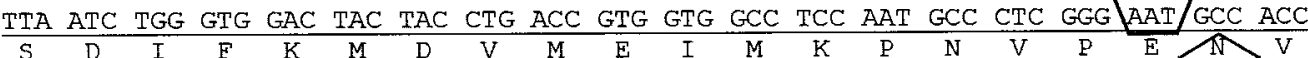
TCA GAC ATC TTT AAA ATG GAC GTG ATG GAA ATC ATG AAG CCC AAT GTT CCT GAA AAT GTA ACG CTG CTG GTG GTG GAG ACG GAG GAC AGT CCA TAT CTC CAT ATC AGA TGG GAA CAT CCC $\begin{array}{llllllllllllllllllll}R & N & T & D & T & E & S & G & W & V & T & I & K & Y & E & \text { L } & R & I & K & Q\end{array}$ CGT AAC ACA GAC ACC GAG TCC GGC TGG GTC ACC ATT AAA TAT GAA CTA AGA ATC AAA CAA $\begin{array}{cccccccccccccccccccc}\mathrm{E} & \mathrm{K} & \mathrm{N} & \mathrm{N} & \mathrm{K} & \mathrm{W} & \mathrm{K} & \mathrm{E} & \mathrm{Y} & \mathrm{M} & \mathrm{S} & \mathrm{G} & \mathrm{T} & \mathrm{Q} & \mathrm{S} & \mathrm{H} & \mathrm{F} & \mathrm{S} & \mathrm{L} & \mathrm{Y} \\ \end{array}$

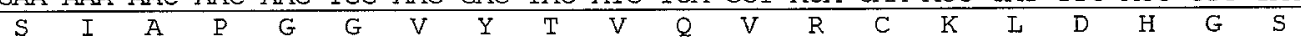
AGC ATC GCT CCT GGA GGG GTT TAC ACA GTT CAG GTG CGC TGT AAA CTG GAC CAC GGA TCC

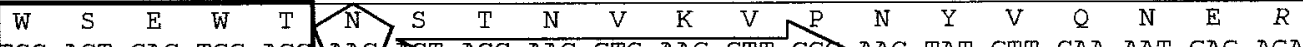

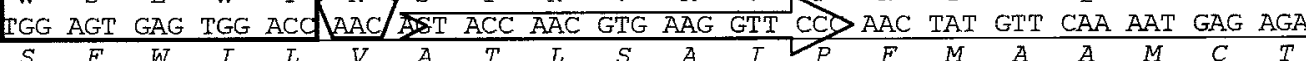
TCG TTT TGG ATC TTG GTC GCC ACC CTG TCT GCA ATT CCA TTT ATG GCA GCA ATG TGC ACC \begin{tabular}{ccccccccccccc|ccccccc|}
\hline$L$ & $I$ & $V$ & $K$ & R & E & $N$ & $V$ & $K$ & $Q$ & $C$ & $V$ & L & P & P & $V$ & P & G & P & K \\
TTG & ATC & GTG & AAG & AGG & GAA & AAT & GTG & AAG & CAG & TGT & GTT & CTG & CCT & CCT & GTT & CCT & GGT & CCA & AAG
\end{tabular}

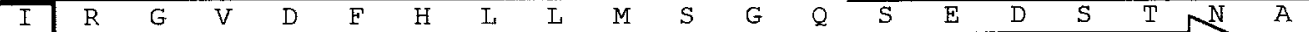
ATC AGA GGA GTT GAT TTT CAC CTC CTC ATG AGT GGADCAA TCT GAA GAC AGC ACC AAD GCC $\begin{array}{lllllllllllllllllll}I & I & I & N & Q & N & F & P & L & I & V & G & W & K & D & Q & M & E & E\end{array}$ CTG ATC ATC AAC CAG AAC TTT CCT CTC ATT GTG GGC TGG AAA GAC CAG ATG GAG GAG TAC \begin{tabular}{cccc|cccccccccccccccc}
\hline I & I & V & T & E & N & D & I & G & P & P & S & D & A & S & H & C & Q & K & R \\
CTC & ATC & GTG & ACA & GAG & AAT & GAC & ATC & GGG & CCT & CCG & TCG & GAT & GCC & TCC & CAT & TGT & CAA & AAA & AGG
\end{tabular}


AAA AAG AGC TTG ATT ATT CCG GCT GGC TTC TGC TCA GAC TGG GAA ATC CAA TGC AAG TCA

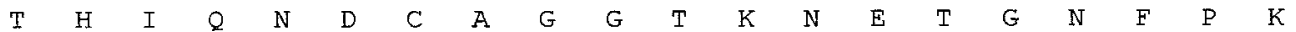
ACC CAC ATT CAG AAT GAC TGT GCA GGG GGA ACA AAG AAT GAA ACG GGT AAC TTT CCC AAG $\begin{array}{llllllllllllllllllll}N & N & K & S & L & S & G & E & S & L & S & K & M & E & P & S & K & L & Q & K\end{array}$ AAC AAT AAG TCT CTC TCA GGG GAG AGT TTA TCT TAC ATG GAG CCA TCC AAG CTG CAG AAA $\begin{array}{cccccccccccccccccccc}Q & Q & C & L & G & Q & N & F & V & N & T & E & A & T & D & P & S & \text { P } & L & \text { N } \\ \text { CAG } & C A G & T G T & T T A & G G T & \text { CAA } & \text { AAC } & \text { TTT } & \text { GTG } & \text { AAC } & \text { ACA } & \text { GAA } & \text { GCA } & \text { TACA } & \text { GAT } & \text { CCC } & \text { AGT } & \text { CCA } & \text { TTG } & \text { AAC }\end{array}$

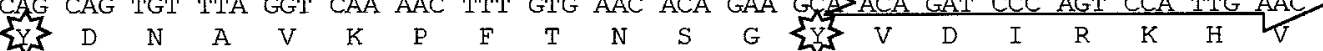
TAC GAC AAT GCT GTC AAA CCC TTC ACA AAC AGC GGC TAT GTG GAT ATT CGG AAA CAT GTG

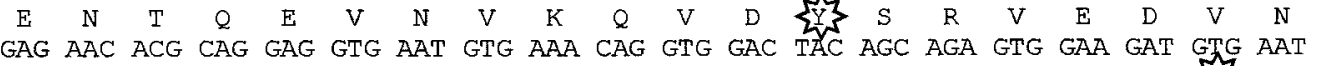

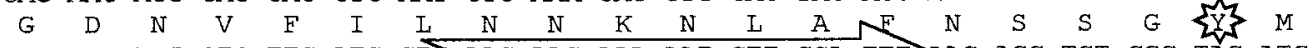
GGT GAC AAP GTG TTC ATC CDE AAC AAC AAA AAT CTI GGA TTP DAC AGC TCT GGC TAC ATG

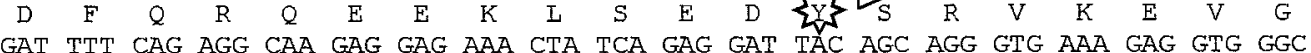
$\begin{array}{llllllllllllllllllll}S & N & N & V & V & V & L & Q & I & Q & D & M & S & A & D & T & K & N & P & H\end{array}$ AGT AAC AAT GTG GTG GTC CTG CAG ATA CAA GAC ATG TCA GCT GAC ACT AAA AAT CCT CAT $\begin{array}{llllllllllllllllllll}A & T & G & A & H & K & M & G & V & C & T & E & L & I & N & S & E & \text { 後 } & I & D\end{array}$ GCG ACT GGA GCC CAC AAA ATG GGG GTG TGC ACA GAA CTC ATC AAT AGC GAA TAT ATA GAT $\begin{array}{cccccccccc}\text { T } & \text { I } & P & \text { A } & \text { P } & \text { P } & \text { L } & \text { M } & \text { * } \\ \text { ACC } & \text { ATC } & \text { CCT } & \text { GCA } & \text { CCA } & \text { CCT } & \text { TTA } & \text { ATG } & \text { TAA } & \text { tgtttagtttaacatgcaatgtccaatacaatggctgatgtC }\end{array}$ ccctatgatttactgttcagagttaaataaaaaggtcgacggtattccatagttttctcaatataatctgaggagtttcc atgacatt tggcaagagacattcatggtcaccagaagataaatcttaccgacttcagtgataccctgaacttccctacag caccatgaagttgccgcttttggttcagagtgaaatatcttgacacttctgaatttattgttgtgaaatttgctacatat attcagggtccccagagaataaacctaagatctttggtgatcctgactctccatcgagccccataatcatgccaaagttt caatcgtccaatactttggtaaataaatatatcaccagacttactgtatataacagtagtttgaattgtaatcattaca taataggatgtaagttttttgggctcaggctaaggtaacttttacaaatctgaaaagaaaaaactctgccactcctt ttggatccttaccactactgggacacctgatgtattatacaacatattgatgtactgaagcacaggtcatgtctggtgtg aagtaaaccatgtgataagatgattactctcagacaggagtattttactccttgtgaaactatggattccttactctga acttgagtacaacctgtttacttccaatccaatatatttggaggaaatacttttttactctgttgtacttttcag ttgtagaggaagtactgatattgaacttcggtaaaatagcaatactacagtgtaaaataccatgtacacgtaaatgtcct attcattataattattgctgtattaaacgataagttcaaccaaaaaaaaaaaaaaa 



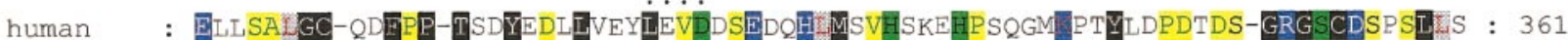

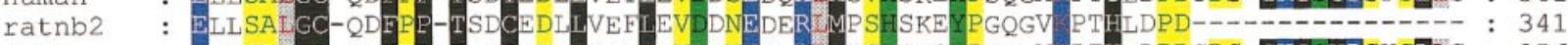

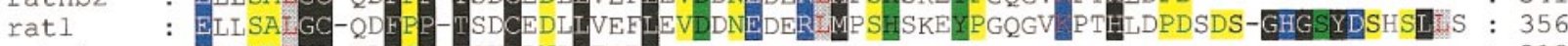
ratsh : KYKVDIYI-ALEG FEILDNAGELDY-

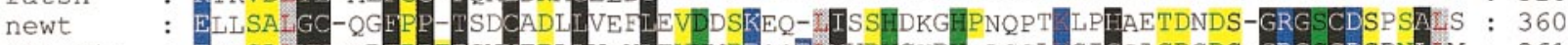

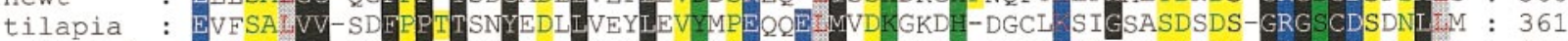
goldfish : EVFNSLVI-QGEPP-TIDYDDLLVEYTEV DNEEQEIVLDSKDL S-EDCM SK-SPSDCDS-GRGSCDSRTILL : 355 seabream :



FIG. 2. Multiple sequence alignment of sea bream PRLR (sbPRLR) with PRLR from several other vertebrates. Colored blocks refer to the physicochemical properties of the amino acids according to the key. Short form of rat PRLR, ratsh; intermediate form of rat PRLR, ratnb2; long form of rat PRLR, rat1; newt PRLR, newt; tilapia PRLR, tilapia; goldfish PRLR, goldfish. On the last line of each block, amino acids identical in all species are indicated by capital letters; small letters represent the most common amino acid in that position. WS box, box 1, and box 2 are indicated. 

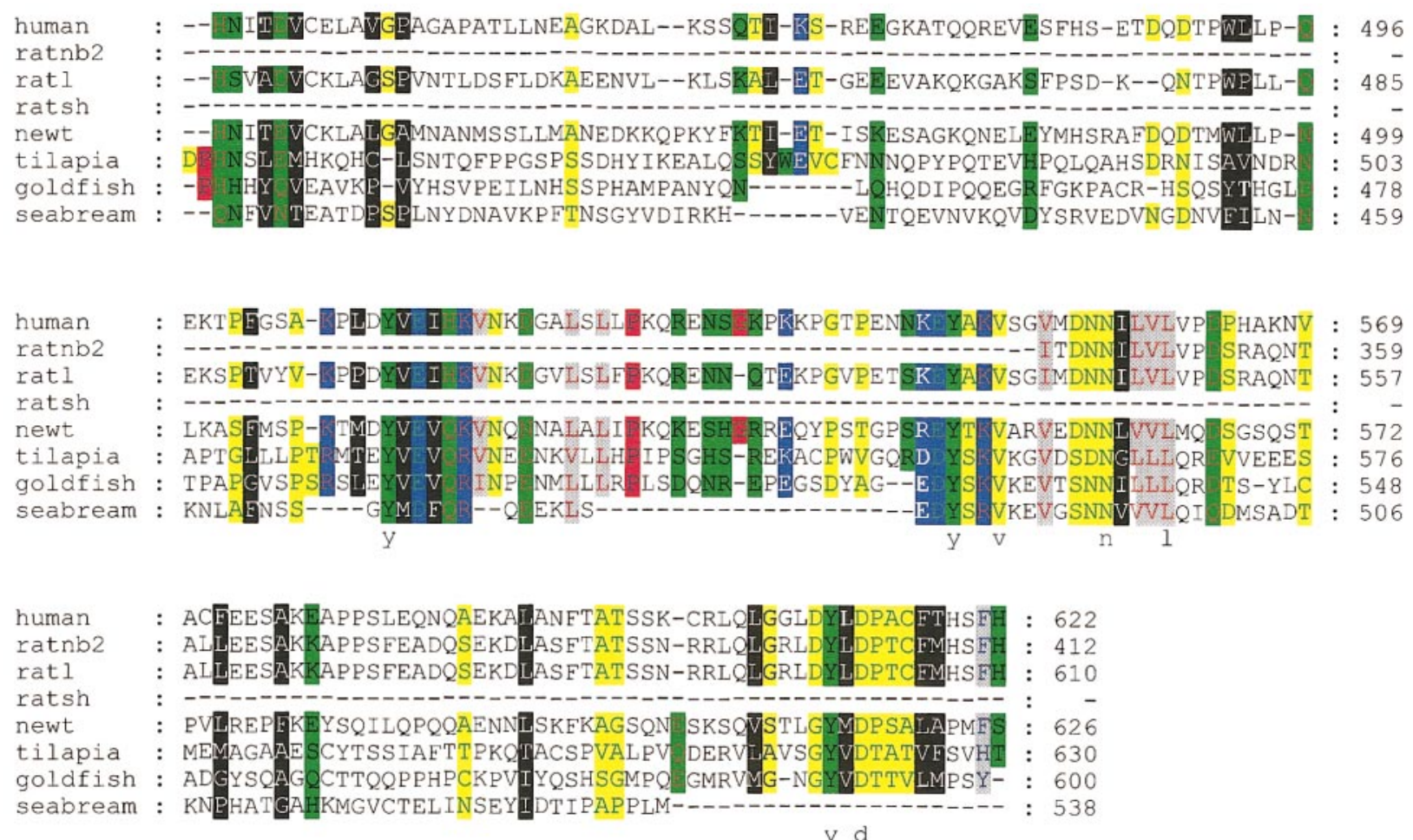

y d

\begin{tabular}{llll}
\hline Proline & X & Charged \\
\hline X Glycine & X & Amphoteric \\
\hline X Tiny & X & Polar \\
X & Small & X & Aliphatic \\
\hline P. Positive & X & Aromatic \\
\hline X. Negative & X & Hydrophobic
\end{tabular}

FIG. 2-Continued

prises 120 nucleotides and the 3'UTR comprises 906 nucleotides. Three clear polyadenylation signals are present at positions 1687, 1919, and 2004 and precede the poly(A) tail.

All the characteristic structural features of PRLRs are present (Fig. 1): two pairs of cysteine residues in the ECD at positions 12,22, 51, and 62, a WS box in which the last serine was conservatively substituted by threonine, the transmembrane domain comprising 24 hydrophobic amino acids and box 1, and a proline-rich region (PPVPGPKI) in the transmembrane proximal to ICD at position 243 . Four potential N-linked glycosylation sites were identified in the ECD. Within the ICD tyrosine residues were found at positions 289, 361, 390, 402, 422, 448, 462, and 507 (Fig. 1).

Multiple sequence alignment of sbPRLR with other previously isolated PRLRs (Fig. 2) shows that the overall identity of sbPRLR with tilapia and goldfish PRLR is 29 and $32 \%$, respectively, and that with mammalian and amphibian counterparts is $23-27 \%$ (Table 1). However, if the physicochemical properties of the amino acids are taken into consideration, receptor sequence conservation is remarkable, not only between fish but also among all vertebrates (Fig. 2). 


\section{TABLE 1}

Amino Acid Identities (\%) in PRLRs from Several Species

\begin{tabular}{lcccccccc}
\hline & Human & Ratnb2 & Rat1 & Ratsh & Newt & Tilapia & Goldfish & Seabream \\
\hline Human & - & 49 & 66 & 33 & 48 & 35 & 33 & 26 \\
Ratnb2 & - & - & 67 & 68 & 35 & 28 & 28 & 25 \\
Rat1 & - & - & - & 46 & 46 & 34 & 33 & 26 \\
Ratsh & - & - & - & - & 25 & 22 & 22 & 23 \\
Newt & - & - & - & - & - & 34 & 36 & 27 \\
Tilapia & - & - & - & - & - & - & 46 & 29 \\
Goldfish & - & - & - & - & - & - & - & 32 \\
\hline
\end{tabular}

Note. Short form of rat PRLR, ratsh; intermediate form of rat PRLR, ratnb2; long form of rat PRLR, rat1; newt PRLR, newt; tilapia PRLR, tilapia; goldfish PRLR, goldfish.

\section{Partial G enomic Sequence of sbPRLR}

PCR of sea bream genomic DNA using primers PR1 and PR2 yielded a 1000-bp fragment. This fragment contains three exons separated by two introns of 540 and $38 \mathrm{bp}$ (Fig. 3). The intron-exon boundaries follow the gt/ag rule (Mount, 1982) and the organization appears to be conserved compared with mouse PRLR gene (Ormandy et al., 1998).

\section{Expression Analysis of sbPRLR by Northern Blot}

Northern blot analysis using $2 \mu \mathrm{g}$ of mRNA (Figs. $4 \mathrm{~A}$ and $4 \mathrm{~B}$ ) demonstrated that PRLR is encoded by two transcripts of 2.8 and $3.2 \mathrm{~kb}$ in the intestine, kidney, and gills. In the pituitary and skin a single transcript of $2.8 \mathrm{~kb}$ was observed. When $10 \mu \mathrm{g}$ of mRNA extracted from spermiating gonads, which contained more than $95 \%$ male tissue (Fig. 4C), was

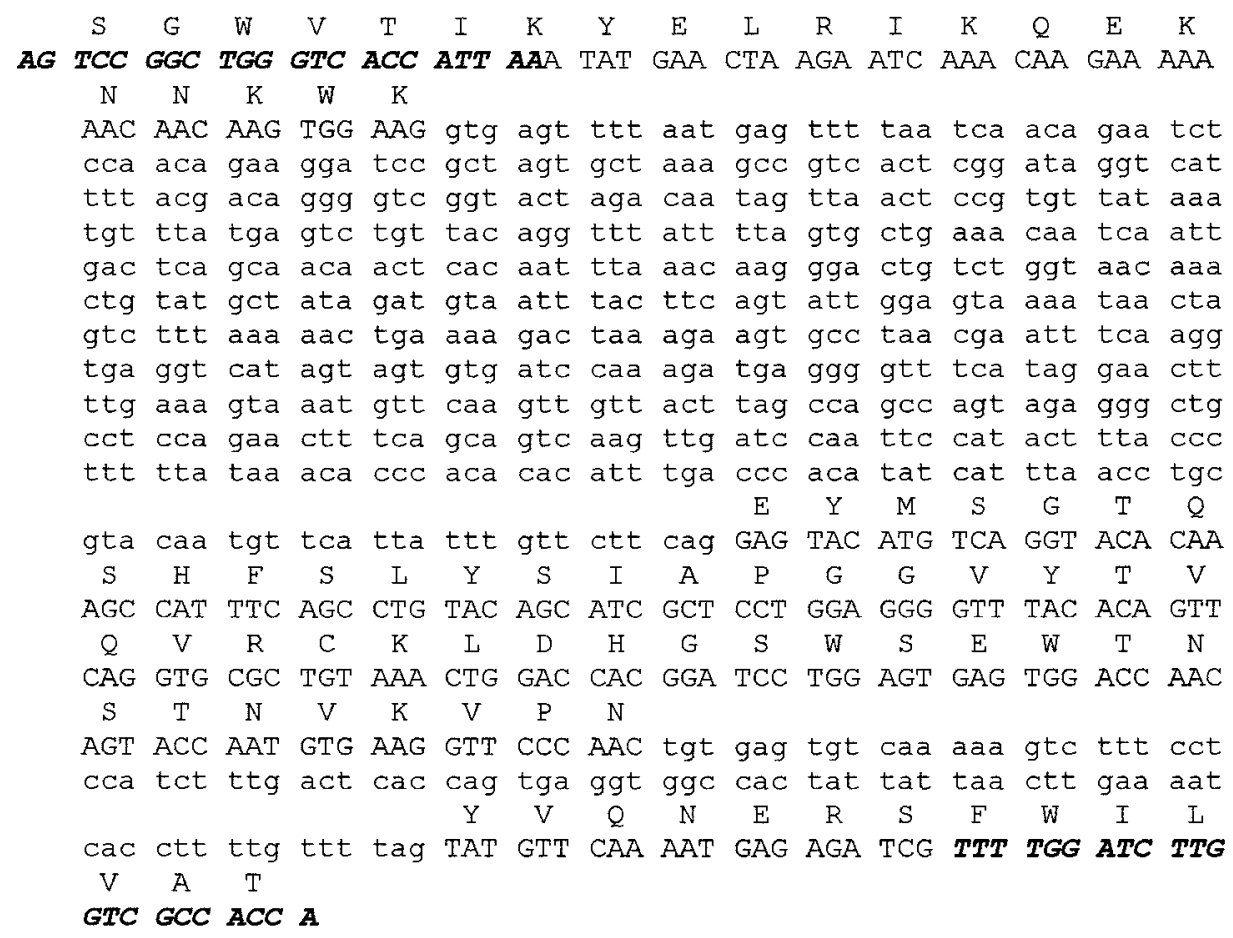

FIG. 3. Nucleotide sequence and deduced amino acid sequence of the PCR-amplified genomic sequence of sea bream PRLR. The primers used are indicated by boldface/italic. The nucleotides corresponding to coding regions are in capitals and those within the noncoding regions are in lowercase letters. 


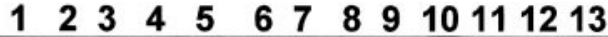

A



B
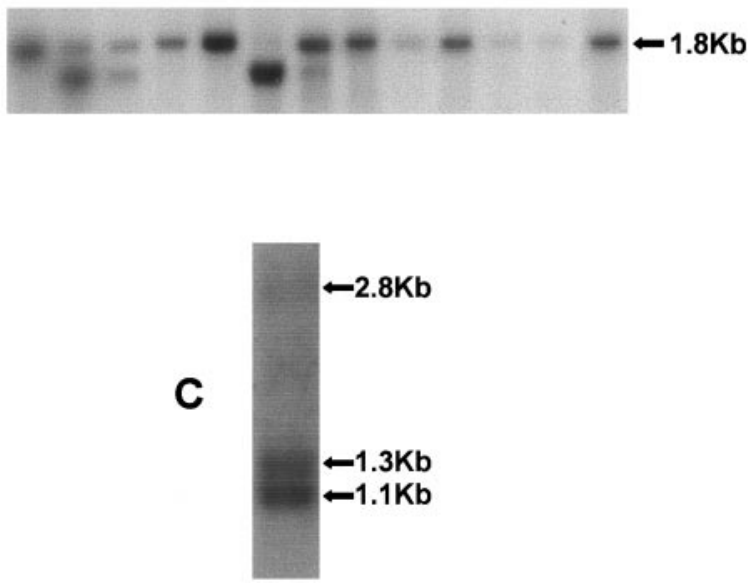

FIG. 4. (A) Northern blot analysis of approximately equivalent quantities of mRNA $(2 \mu \mathrm{g})$ from several sea bream tissues. With the exception of sample 2, all are from adult fish: 1, head-kidney; 2, larvae; 3 , skin; 4, brain; 5 , kidney; 6 , muscle; 7 , gill; 8 , spleen; 9 , liver; 10, intestine; 11, testis; 12, ovary; 13, pituitary. Hybridization was carried out with sbPRLR (clone I3A2). (B) Results obtained from the hybridization of the same filter with sea bream $\beta$-actin. (C) Northern blot analysis of mRNA $(10 \mu \mathrm{g})$ extracted from mature (spermiating) male gonads. Hybridization was carried out with sbPRLR (clone I3A2). The arrows on the right side of the filter indicate transcript size.

analyzed, the major transcripts identified were 1.3 and $1.1 \mathrm{~kb}$. The 2.8-kb transcript, which was the principle transcript in larvae, skin, kidney, gill, and pituitary, was present, but at low levels, in gonads and a further transcript of $1.9 \mathrm{~kb}$ was observed in gonads. Intestine, gill, kidney, and pituitary had the highest levels of PRLR expression and no signal was detected in the other tissues analyzed using the same amount of mRNA (Fig. 4A).

\section{Tissue Distribution by RT -PCR}

RT-PCR with sea bream receptor-specific primers of approximately equivalent quantities of cDNA from kidney, skin, gill, intestine, brain, testis, ovary, liver, skeletal muscle, heart, and bone resulted in detection of transcripts in gill and intestine (Figs. 5A and $5 \mathrm{~B})$. The Southern blot of these reactions also permitted detection of PRLR transcripts in skin, kidney, brain, testis, ovary, and liver (Fig. 5C). Although no signal was visible in skeletal muscle, heart, and bone after the blot had been exposed for 5 min (Fig. 5C), longer exposure time ( $2 \mathrm{~h}$ ) permitted detection of PRLR transcripts in these tissues (Fig. 5D).

\section{Immunohistochemistry of Sea Bream Tissues}

Only tissues from juvenile sea bream were examined for PRLR distribution by specific immunohistochemistry using antiserum to an oligopeptide of the external domain of the receptor; some of these are illustrated in Fig. 7. The antiserum used for these studies was prepared by conjugation of a specific oligopeptide to bovine thyroglobulin. When tested for the presence of antibodies to thyroglobulin, the antiserum produced only a weak reaction with colloid of thyroid follicles in sea bream. This cross-reaction could be eliminated by incubation with bovine thyroglobulin without significant effect on specific reaction with PRLR in other tissues; this effect is illustrated in Figs. 6A-6D. Figure 6A shows

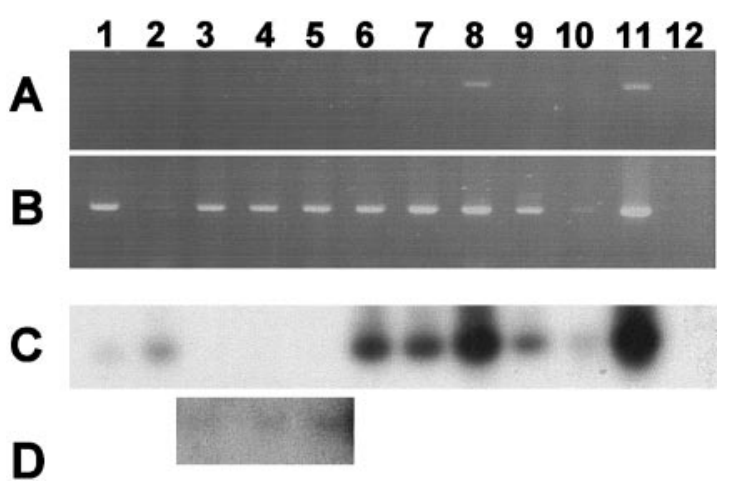

FIG. 5. (A) Distribution of PRLR in adult tissues by RT-PCR: 1, brain; 2 , testis; 3 , heart; 4 , muscle; 5 , bone; 6 , kidney; 7 , skin; 8 , gills; 9, ovary; 10, liver; 11 , intestine; 12, PCR negative control. (B) The cDNA used to determine PRLR tissue distribution were also amplified with sea bream $\beta$-actin primers to evaluate the relative amount of cDNA used in each PCR. (C) Southern blot of the reactions shown in A (5 min exposure). (D) Heart, muscle, and bone samples after $2 \mathrm{~h}$ exposure. The sensitivity of RT-PCR coupled with Southern blotting permitted detection of PRLR transcripts in brain, testis, kidney, skin, gills, ovary, liver, and intestine after $5 \mathrm{~min}$ exposure and in heart, muscle, and bone after $2 \mathrm{~h}$ exposure. 


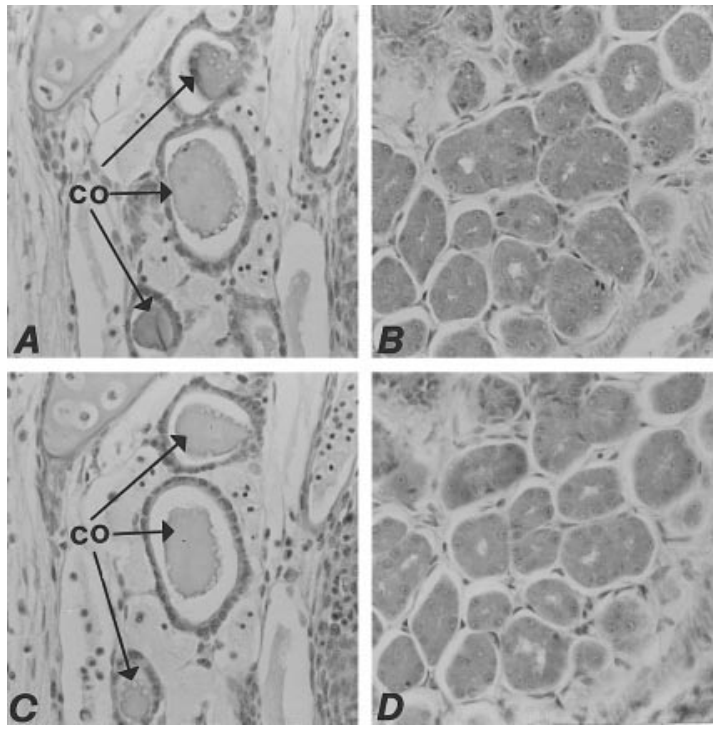

FIG. 6. Immunohistochemistry of thyroid follicles of sea bream (A and $\mathrm{C}$ ) and proventricular gland cells (B and D). (A and B) show immunoreaction with unabsorbed antiserum to PRLR peptide antibody conjugated to bovine thyroglobulin, and ( $C$ and $D)$ are adjacent sections reacted with the same antiserm absorbed with bovine thyroglobulin. Immunoreaction has been abrogated only in thyroid follicle colloid (co) by thyroglobulin absorption (cf. A and C).

reaction with unabsorbed antiserum with colloid in thyroid follicles, and in Fig. 6B there is strong reaction with the proventricular gland cells on the same section. Figures $6 \mathrm{C}$ and $6 \mathrm{D}$ show the same areas of tissue as those from the adjacent section but reacted with antiserum absorbed with bovine thyroglobulin. The weak reaction in thyroid colloid was absorbed by thyroglobulin but the reaction in the proventricular cells was not reduced.

Figure 7 shows immunoreactions in renal tubules (Fig. 7B) and gut epithelium, with the most intense reaction in the basal glandular region of the proventriculus (Fig. 7A); epithelia of other regions of the gut contained only low levels of receptor protein. In the gill, the chloride cells of the filament epithelium reacted strongly (Fig. 7E) but stromal cells of the fibrous cartilage of the gill bars appeared to contain abundant receptor protein (Fig. 7C). The single layer of epithelial cells of the choroid plexus was rich in receptor protein (Fig. 7D) and it is interesting that the epithelial cells of the saccus vasculosus also contained prolactin receptors (Fig. 7F).

\section{DISCUSSION}

The present study describes the cloning and characterization of a PRLR in a marine teleost. Conservation of all the structural and functional features characteristic of PRLRs, the physicochemical properties, both in the ECD and in the ICD, and gene organization, substantiate the identification of this protein as a PRLR and make it improbable that it is a receptor for another member of the growth hormone/PRL gene family.

The tissue distribution of the receptor was determined in adult fish both by Northern blotting, which permitted the identification of size and number of transcripts, and by the more sensitive method of RTPCR, which allowed detection of PRLR in tissue with low transcript number. Cellular localization of PRLR protein was determined by IHC with a sea breamspecific receptor antiserum. In addition, part of the genomic organization of sbPRLR was elucidated and compared to the PRLR gene of mammals.

PRLR in the sea bream exhibits all the characteristic features of long forms of PRLRs. In common with other species sbPRLR contains a single transmembrane spanning domain and an ECD and ICD. The ECD comprises 208 amino acids and contains two pairs of cysteines which were identified at positions topologically equivalent to those of the mammalian, amphibian, and other fish PRLR, representing areas of high homology. In mammals these two pairs of cysteines form ligation pockets specific for each ligand and mutational studies demonstrated that they are important for receptor structure and function (Rozakis-Adcock and Kelly, 1991, 1992). The similar constitution and organization in SbPRLR, as well as in the other fish, suggest a common function. In the WS box of the ECD, there has been a conservative substitution of the last serine by threonine; an identical substitution is present in goldfish (Tse et al., 2000) and in mouse (Davis and Linzer, 1989) serine has been replaced by glycine. The WS box can be found in all the members of the class 1 superfamily of cytokine receptors with the exception of the growth hormone receptor (GHR), in which conservative substitutions have occurred (Kelly et al., 1991a). The high degree of conservation of the WS box suggests that it has an important role in receptor function, and mutations in this 

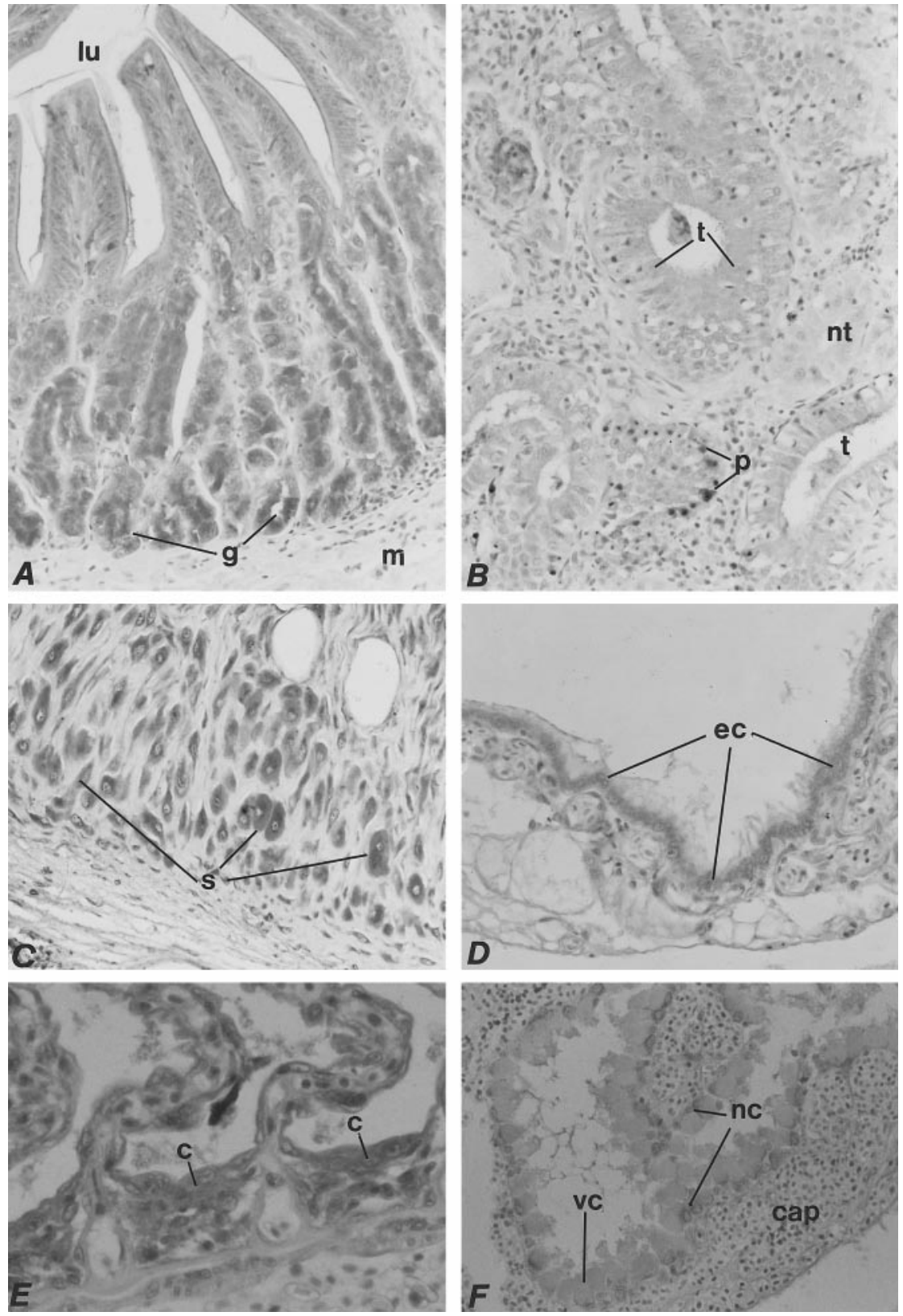

FIG. 7. Immunohistochemistry of some tissues from juvenile sea bream using rabbit antiserum to an oligopeptide in the external domain of the prolactin receptor. (A) The proventricular region of the gut showed the strongest reaction of all the gut epithelia; moreover, the basal glandular cells $(\mathrm{g})$ of this region appear to have greater content of receptor protein. There is also immunostaining in the epithelial cells lining the lumen of the gut (lu), but no reaction in the smooth muscle $(\mathrm{m})$. (B) A section through the renal kidney showing immunostaining in epithelial cells of some tubules ( $\mathrm{t}$ ), but no reaction in smaller proximal tubules (nt). The reaction in most epithelial cells is spread throughout the cytoplasm but in others it is concentrated in the basal region of the cell as punctate bodies (p). (C) Fibrous cartilage of the gill bars showing strong reaction in the stromal cells (s). (D) There is a strong prolactin receptor immunoreaction in the single layer of epithelial cells of the choroid (ec) of the midbrain. (E) Section of a gill filament showing prolactin receptors in the chloride cells (c). (F) Epithelial cells of the saccus vasculosus showed two patterns of immunostaining similar to the kidney tubule cells in B. In some cells prolactin receptors appeared to be spread throughout the cytoplasm (vc) but in others there was also a concentration around the nucleus (nc) in the basal portion of the cell adjacent to the capillary (cap). 
region are detrimental to receptor affinity (RozakisAdcock et al., 1991), suggesting a role in ligand binding. It seems that the WS motif is required for maintenance of the correct folding of the molecule (Goffin et al., 1998). In common with mammalian PRLR, the ECD of sbPRLR contains four potential N-linked glycosylation sites, although their relative positions are not conserved. In tiPRLR only two N-linked glycosylation sites were found. The importance of glycosylation sites for adoption of an active conformation of PRLR has been demonstrated in rat (Buteau et al., 1998) but is unknown for other species, including fish. Unlike in avian species, tandem repeats (Chen and Horseman, 1994; Zhou et al., 1996) were not identified within the ECD of sbPRLR. The transmembrane domain of sbPRLR comprises 24 amino acids and shares the hydrophobic properties described for previously characterized PRLRs. The ICD of sbPRLR comprises 284 amino acids and contains the proline-rich motif (box 1), which shares 100\% identity with all PRLRs known so far. This is by far the most highly conserved region within the PRLRs ICD among cytokine receptors and it plays an important role in the signal transduction pathway (Dinerstein et al., 1995; Pezet et al., 1997). The ICD of different PRLR forms varies in size and several isoforms of PRLR which differ from each other in length and composition have been found in the same species (Boutin et al., 1989, 1988; Shirota et al., 1990). Additional important structural and functional features are also present in sbPRLR ICD and include box 2 and several tyrosine residues. In general sbPRLR resembles the long form of PRLR, although six deletions scattered throughout the ICD, which lacks 6-21 amino acids, make it 62-92 residues shorter than all the other long forms of PRLR so far identified. Most of these deletions are also present in gfPRLR but do not occur in tiPRLR.

Despite the presence of all the characteristic features of PRLRs, the amino acid sequence of sbPRLR shares a relatively low level of identity with tiPRLR (Sandra et al., 1995) and gfPRLR (Tse et al., 2000). However, sequence identity is higher $(46 \%)$ in tilapia and goldfish PRLR. Whether the sequence differences observed in fish PRLR are important for specific functions of the PRLR and related to differences in the environment that they inhabit remains to be examined; for example, tilapia is euryhaline and goldfish is a freshwater stenohaline species.
Nevertheless, it appears that PRLR are more variable (29-46\% sequence identity) among fishes than among mammals, birds, and amphibia, which share $71-83 \%$ sequence identity. However, since there are many more species of teleost fish than all the rest of the vertebrates, it is too early to make general comparisons. It is important to note, however, that the motifs known to be essential for the mechanisms of signal transduction are conserved, suggesting that similar mechanisms operate throughout the vertebrates. If the physicochemical properties of the amino acids are taken into consideration, conservation is remarkable, principally in the ECD but also within the ICD. Even though the amino acid composition of the receptors varies, substitutions, which occurred during evolution, appear to have preserved the overall physicochemical properties of the receptor. Analysis of a partial sequence of genomic DNA for sbPRLR shows that, within the region analyzed, gene organization also appears to have been conserved and resembles that of the mouse (Ormandy et al., 1998). In particular, the sea bream WS box and transmembrane domain, in common with the situation reported in mouse, are coded by different exons.

Northern blot analysis of several sea bream tissues revealed the presence of two differently sized transcripts, which had differential levels of expression in the diverse tissues analyzed. In gills, intestine, and kidney, both transcripts could be observed, though the $2.8-\mathrm{kb}$ transcript was predominant in gills and kidney, whereas the 3.2-kb transcript appears to be more abundant in the intestine. In the pituitary and skin, only the smaller transcript was observed. In addition, the gonads contained three further transcripts of 1.9, 1.3, and $1.1 \mathrm{~kb}$, suggesting that more than one form of PRLR is transcribed in the sea bream gonad. It is possible that these three transcripts encode a short form of PRLR. The expression of PRLR in sea bream differs from that reported in tilapia, in which a single transcript of $3.2 \mathrm{~kb}$ was identified, and although more than one transcript of gfPRLR has been identified, they are much larger, 4.6 and $3.5 \mathrm{~kb}$. The existence of alternative forms of PRLR in the sea bream remains to be clarified but expression may be more like that of mouse, in which several transcripts encode the long and short forms of PRLR in a tissue-specific 
pattern (Buck et al., 1992) as a consequence of alternative splicing of the same gene (Ormandy et al., 1998). Moreover, in sea bream, Northern blotting demonstrated that the intestine, gill, kidney, and pituitary are the tissues expressing sbPRLR at the highest levels. PRL has long been recognized as a freshwater-adapting hormone in fish. In fish adapted to hyperosmotic environments, PRL is known to modulate the absorption of $\mathrm{NaCl}$ in the gastrointestinal tract (Morley et al., 1981) and in hyposmotic environments, PRL reduces branchial sodium efflux and water permeability of gills, renal tubules, intestine, and urinary bladder; some of these actions are due to a reduction to $\mathrm{Na}^{+} \mathrm{K}^{+}$ATPase activity (Flick et al., 1994; Shepherd et al., 1997). Adult sea bream spend their life in a marine environment without a severe hydromineral challenge; nevertheless, the high level of expression of receptor in the osmoregulatory organs suggests that these are important targets for PRL and raises intriguing questions about the function of PRL at these sites in this marine teleost. In tilapia, somewhat paradoxically, there was an increase in PRLR numbers in fish transferred from fresh to brackish water (Auperin et al., 1995), suggesting that they are prepared for unexpected changes in external ionic or osmotic concentrations. The expression of PRLR in skin may suggest a function at the level of hydromineral balance or at the level of fish immunoprotection. Fish skin is a major barrier against external aggressions and pathogens and PRL enhances the production of mucus, which further protects the animal. This mechanism of protection has already been described in other species of fish (Sage, 1970). The presence of PRLR transcripts in the gonads suggests a likely involvement of PRL in the reproductive cycle of this species. Sea bream is a protandrous hermaphrodite (Hape and Zohar, 1988). The mechanisms underlying its sex reversal are still poorly understood, although it appears that estrogens induce feminization of the gonads, whereas androgens induce masculinization (Badura and Friedman, 1988; Hape and Zohar, 1988; Condeça and Canario, 1999). The involvement of PRL in the production of steroid hormones and the onset of gonadal development has already been reported in cichlid species (Rubin and Specker, 1992; Tan et al., 1988), suggesting that PRL may be involved in the process of sex reversal through control of steroid production and may also be involved in control of gonad maturation.

The analysis of receptor tissue distribution carried out by RT-PCR supports the results obtained by Northern blotting and IHC, and due to its higher sensitivity, PRLR expression was detected in other tissues, such as the liver, muscle, bone, and brain, suggesting that PRL may also be involved in growth and behavior, other putative functions already described in cichlid fish (Blum and Fiedler, 1965; Lam and Hoar, 1967; Shepherd et al., 1997).

Immunohistochemistry of PRLR in tissues of sea bream using the antibody to an oligopeptide of the external domain of the receptor showed specific reaction in several tissues. Reaction with thyroglobulin, the carrier protein of the peptide immunogen, was shown to be weak and occurred only with the thyroglobulin-rich colloid within the thyroid follicles.

Distribution of specific PRLR was noted in tissues concerned with control of water and ion balance, including gills, intestine, and renal tubule epithelium. Although PRL is associated with survival of euryhaline fish in water of low osmotic potential, principally by inhibition of sodium loss, PRL receptors have also been shown to increase in gills of Oreochromis niloticus when transferred from fresh water to brackish water (Auperin et al., 1995). The presence of PRLR in these epithelial cells may suggest roles for PRL other than ion and water regulation since PRL influences the cell cycle, through inhibition of apoptosis and differentiation (Clarke and Bern, 1980; Hirano, 1986). The presence of PRLR in the saccus vasculosus and in the choroid plexus may be related to the function of these epithelia in monitoring the composition of cerebrospinal fluid in relation to plasma composition. PRLR have been described in the choroid plexus epithelia of other vertebrates (Posner et al., 1983; Buntin and Walsh, 1988; Muccioli et al., 1988) and their presence in fish suggests that they are an earlier evolutionary development. PRLR also occur in mesodermally derived connective tissues, having been described in mammalian chondrocytes of developing cartilage and mesenchymal precartilage (Freemark et al., 1997), and their recent detection in osteoblasts (Clement-Lacroix et al., 1999) shows that they do have a role(s) in skeletal tissues. Only further physiological studies will determine the functions of PRL through receptor binding in these various tissues. 


\section{REFERENCES}

Ali, S., Pellegrini, I., and Kelly, P. A. (1991). A prolactin-dependent immune cell line $(\mathrm{Nb} 2)$ expresses a mutant form of prolactin receptor. J. Biol. Chem. 266, 20110-20117.

Auperin, B., Rentier-Delrue, F., Martial, J. A., and Prunet, P. (1994). Characterization of a single prolactin (PRL) receptor in tilapia (Oreochromis niloticus) which binds both PRLI and PRLII. J. Mol. Endocrinol. 13, 241-251.

Auperin, B., Rentier-Delrue, F., Martial, J. A., and Prunet, P. (1995). Regulation of gill prolactin receptors in tilapia (Oreochromis niloticus) after a change in salinity or hypophysectomy. J. Endocrinol. 145, 213-220.

Aviv, H., and Leder, P. (1972). Purification of biologically active globin messenger RNA by chromatography on oligothymidylic acid-cellulose. Proc. Natl. Acad. Sci. USA 69, 1408-1412.

Badura, L. L., and Friedman, H. (1988). Sex reversal in female Betta splendens as a function of testosterone manipulation and social influence. J. Comp. Psychol. 102, 262-268.

Bern, H. A. (1975). Prolactin osmoregulation. Am. Zool. 15, 937-948. Bignon, C., Binart, N., Ormandy, C., Schuler, L. A., Kelly, P. A., and Djiane, J. (1997). Long and short forms of the ovine prolactin receptor: cDNA cloning and genomic analysis reveal that the two forms arise by different alternative splicing mechanisms in ruminants and in rodents. J. Mol. Endocrinol. 19, 109-120.

Blum, V., and Fiedler, K. (1965). Hormonal control of reproductive behavior in some cichlid fish. Gen. Comp. Endocrinol. 5, 186-196.

Bole-Feysot, C., Goffin, V., Edery, M., Binart, N., and Kelly, P. A. (1998). Prolactin (PRL) and its receptor: Actions, signal transduction pathways and phenotypes observed in PRL receptor knockout mice. Endocr. Rev. 19, 225-268.

Boutin, J. M., Edery, M., Shirota, M., Jolicoeur, C., Lesueur, L., Ali, S., Gould, D., Djiane, J., and Kelly, P. A. (1989). Identification of a cDNA encoding a long form of prolactin receptor in human hepatoma and breast cancer cells. Mol. Endocrinol. 3, 1455-1461.

Boutin, J. M., Jolicoeur, C., Okamura, H., Gagnon, J., Edery, M., Shirota, M., Banville, D., Dusanter-Fourt, I., Djiane, J., and Kelly, P. A. (1988). Cloning and expression of the rat prolactin receptor, a member of the growth hormone/prolactin receptor gene family. Cell 53, 69-77.

Buck, K., Vanek, M., Groner, B., and Ball, R. K. (1992). Multiple forms of prolactin receptor messenger ribonucleic acid are specifically expressed and regulated in murine tissues and the mammary cell line HC11. Endocrinology 130, 1108-1114.

Buntin, J. D., and Walsh, R. J. (1988). In vivo autoradiographic analysis of prolactin binding in brain and choroid plexus of the domestic ring dove. Cell Tissue Res. 251, 105-109.

Buteau, H., Pezet, A., Ferrag, F., Perrot-Applanat, M., Kelly, P. A., and Edery, M. (1998). N-glycosylation of the prolactin receptor is not required for activation of gene transcription but is crucial for its cell surface targeting. Mol. Endocrinol. 12, 544-555.

Clarke, W. C., and Bern, H. A. (1980). Comparative endocrinology of prolactin. In "Hormonal Proteins and Peptides" (C. H. Li, Ed.), Vol. VIII, pp. 105-197. Academic Press, New York.
Chen, X., and Horseman, N. D. (1994). Cloning, expression, and mutational analysis of the pigeon prolactin receptor. Endocrinology 135, 269-276.

Clement-Lacroix, P., Ormandy, C., Lepescheux, L., Ammann, P., Damotte, D., Goffin, V., Bouchard, B., Amling, M., Gaillard-Kelly, M., Binart, N., Baron, R., and Kelly, P. A. (1999). Osteoblasts are a new target for prolactin: Analysis of bone formation in prolactin receptor knockout mice. Endocrinology 140, 96-105.

Condeça, J. B., and Canario, A. V. M. (1999). The effect of estrogen on the gonads and on in vitro conversion of androstenione to testosterone, 11-ketotestosterone, and estradiol-17 $\beta$ in Sparus aurata (Teleostei, Sparidae). Gen. Comp. Endocrinol. 116, 59-72.

Das, R., and Vonderhaar, B. K. (1995). Transduction of prolactin's (PRL) growth signal through both long and short forms of the PRL receptor. Mol. Endocrinol. 9, 1750-1759.

Davis, J. A., and Linzer, D. I. (1989). Expression of multiple forms of the prolactin receptor in mouse liver. Mol. Endocrinol. 3, 674-680.

Di Carlo, R., Muccioli, G., Papotti, M., and Bussolati, G. (1992). Characterization of prolactin receptor in human brain and choroid plexus. Brain Res. 570, 341-346.

Dinerstein, H., Lago, F., Goujon, L., Ferrag, F., Esposito, N., Finidori, J., Kelly, P. A., and Postel-Vinay, M. C. (1995). The proline-rich region of the $\mathrm{GH}$ receptor is essential for JAK2 phosphorylation, activation of cell proliferation, and gene transcription. Mol. Endocrinol. 9, 1701-1707.

Dusanter-Fourt, I., Gaye, P., Belair, L., Petridou, B., Kelly, P. A., and Djiane, J. (1991). Prolactin receptor gene expression in the rabbit: Identification, characterization and tissue distribution of several prolactin receptor messenger RNAs encoding a unique precursor. Mol. Cell. Endocrinol. 77, 181-192.

Dusanter-Fourt, I., Kelly, P. A., and Djiane, J. (1987). Immunological recognition of the prolactin receptor: Identification of a single binding unit of molecular weight approximately 42,000. Biochimie 69, 639-646.

Edery, M., Jolicoeur, C., Levi-Meyrueis, C., Dusanter-Fourt, I., Petridou, B., Boutin, J. M., Lesueur, L., Kelly, P. A., and Djiane, J. (1989). Identification and sequence analysis of a second form of prolactin receptor by molecular cloning of complementary DNA from rabbit mammary gland. Proc. Natl. Acad. Sci. USA 86, 2112-2116.

Finidori, J., and Kelly, P. A. (1995). Cytokine receptor signalling through two novel families of transducer molecules: Janus kinases, and signal transducers and activators of transcription. $J$. Endocrinol. 147, 11-23.

Freemark, M., Driscoll, P., Maaskant, R., Petryk, A., and Kelly, P. A. (1997). Ontogenesis of prolactin receptors in the human fetus in early gestation-Implications for tissue differentiation and development. J. Clin. Invest. 99, 1107-1117.

Flick, G., Rentier-Delrue, F., and Wendelaar Bonga, S. E. (1994). Calcitropic effects of recombinant prolactins in Oreochromis mossambicus. Am. J. Physiol. 15, R1302-R1308.

Goffin, V., Bouchard, B., Ormandy, C. J., Weimann, E., Ferrag, F., Touraine, P., Bole-Feysot, C., Maaskant, R. A., Clement-Lacroix, P., Edery, M., Binart, N., and Kelly, P. A. (1998). Prolactin: A hormone at the crossroads of neuroimmunoendocrinology. Ann. N. Y. Acad. Sci. 840, 498-509. 
Goupille, O., Daniel, N., Bignon, C., Jolivet, G., and Djiane, J. (1997). Prolactin signal transduction to milk protein genes: Carboxyterminal part of the prolactin receptor and its tyrosine phosphorylation are not obligatory for JAK2 and STAT5 activation. Mol. Cell. Endocrinol. 127, 155-169.

Happe, A., and Zohar, Y. (1988). Self-fertilization in the protandrous hermaphrodite Sparus aurata: Development of the technology. In "Reproduction in Fish-Basic and Applied Aspects in Endocrinology and Genetics" (Y. Zohar and B. Breton, Eds.), pp. 177-180. Les Colloques de l'INRA, No. 44. INRA, Paris.

Hirano, T. (1986). The spectrum of prolactin action in teleosts. In "Comparative Endocrinology: Developments and Directions" (C. L. Ralph, Ed.), pp. 53-74. A. R. Liss, New York.

Kelly, P. A., Ali, S., Rozakis, M., Goujon, L., Nagano, M., Pellegrini, I., Gould, D., Djiane, J., Edery, M., Finidori, J., et al. (1993). The growth hormone/prolactin receptor family. Recent Prog. Horm. Res. 48, 123-164.

Kelly, P. A., Djiane, J., Banville, D., Ali, S., Edery, M., and Rozakis, M. (1991a). The growth hormone/prolactin receptor gene family. Oxf. Surv. Eukaryot. Genes 7, 29-50.

Kelly, P. A., Djiane, J., Postel-Vinay, M. C., and Edery, M. (1991b). The prolactin/growth hormone receptor family. Endocr. Ver. 12, 235-251.

Kraicer, J., Herlant, M., and Duclos, P. (1967). Changes in adenohypophyseal cytology and nucleic acid content in the rat 32 days after adrenalectomy and the chronic injection of cortisol. Can. J. Pharmacol. Physiol. 45, 947-956.

Lam, T., and Hoar, W. (1967). Seasonal effects of prolactin on fresh-water osmoregulation of the marine form (trachurus) of the stickleback Gasterosteus aculeatus. Can. J. Zool. 45, 509-516.

Moore, R. C., and Oka, T. (1993). Cloning and sequencing of the cDNA encoding the murine mammary gland long-form prolactin receptor. Gene 134, 263-265.

Morley, M., Chadwick, A., and El Tounsy, E. M. (1981). The effect of prolactin on water absorption by the intestine of the trout (Salmo gairdneri). Gen. Comp. Endocrinol. 44, 64-68.

Mount, S. M. (1982). A catalogue of splice junction sequences. $\mathrm{Nu}$ cleic Acids Res. 10, 459-472.

Muccioloi, G., Bellussi, G., Ghe, C., Pagnini, G., and Di Carlo, R. (1988). Regional distribution and species variations of prolactin binding-sites in the brain. Gen. Comp. Endocrinol. 69, 399-405.

Nevalainen, M. T., Valve, E. M., Ingleton, P. M., and Härkönen, P. L. (1996). Expression and hormone regulation of prolactin receptors in rat dorsal and lateral prostate in organ culture. Endocrinology 137, 3078-3088.

Ormandy, C. J., Binart, N., Helloco, C., and Kelly, P. A. (1998). Mouse prolactin receptor gene: Genomic organization reveals alternative promoter usage and generation of isoforms via alternative 3 '-exon splicing. DNA Cell. Biol. 17, 761-770.

Pezet, A., Buteau, H., Kelly, P. A., and Edery, M. (1997). The last proline of Box 1 is essential for association with JAK2 and functional activation of the prolactin receptor. Mol. Cell. Endocrinol. 129, 199-208.

Posner, B. I., van Houten, M., Patel, B., and Walsh, R. J. (1983). Characterisation of lactogen binding sites in choroid plexus. Exp. Brain Res. 49, 300-306.
Rozakis-Adcock, M., and Kelly, P. A. (1991). Mutational analysis of the ligand-binding domain of the prolactin receptor. J. Biol. Chem. 266, 16472-16477.

Rozakis-Adcock, M., and Kelly, P. A. (1992). Identification of ligand binding determinants of the prolactin receptor. J. Biol. Chem. 267, 7428-7433.

Rubin, D. A., and Specker, J. L. (1992). In vitro effects of homologous prolactins on testosterone production by testes of tilapia (Oreochromis mossambicus). Gen. Comp. Endocrinol. 87, 189-196.

Sage, M. (1970). Control of prolactin release and its role in color change in the teleost Gillichthys mirabilis. J. Exp. Zool. 173, 121-127.

Sandra, O., Le Rouzic, P., Cauty, C., Edery, M., and Prunet, P. (2000). Expression of the prolactin receptor (tiPRL-R) gene in tilapia Oreochromis niloticus: Tissue distribution and cellular localization in osmoregulatory organs. J. Mol. Endocrinol. 24, 215-224.

Sandra, O., Sohm, F., de Luze, A., Prunet, P., Edery, M., and Kelly, P. A. (1995). Expression cloning of a cDNA encoding a fish prolactin receptor. Proc. Natl. Acad. Sci. USA 92, 6037-6041.

Sanger, F., Nicklen, S., and Coulson, A. R. (1977). DNA sequencing with chain-terminating inhibitors. Proc. Natl. Acad. Sci. USA 74, 5463-5467.

Santos, C. R. A., Power, D. M., Kille, P., Llwellyn, L., Ramsurn, V., Wigham, T., and Sweeney, G. E. (1997). Cloning and sequencing of a full length sea bream (Sparus aurata) $\beta$-actin cDNA. Comp. Biochem. Physiol. B 117, 185-189.

Santos, C. R. A., Brinca, L., Ingleton, P. M., and Power, D. M. (1999). Cloning, expression, and tissue localization of prolactin in adult sea bream (Sparus aurata). Gen. Comp. Endocrinol. 114, 57-66.

Shepherd, B. S., Sakamoto, T., Nishioka, R. S., Richman, N. H., 3rd, Mori, I., Madsen, S. S., Chen, T. T., Hirano, T., Bern, H. A., and Grau, E. G. (1997). Somatotropic actions of the homologous growth hormone and prolactins in the euryhaline teleost, the tilapia, Oreochromis mossambicus. Proc. Natl. Acad. Sci. USA 94, 2068-2072.

Shirota, M., Banville, D., Ali, S., Jolicoeur, C., Boutin, J. M., Edery, M., Djiane, J., and Kelly, P. A. (1990). Expression of two forms of prolactin receptor in rat ovary and liver. Mol. Endocrinol. 4, 11361143.

Sternberger, L. A. (1974). "Immunocytochemistry." Prentice-Hall, Englewood Cliffs, NJ.

Tan, C., Wong, L., Pang, M., and Lam, T. (1988). Tilapia prolactin stimulates estradiol-17b synthesis in vitro in vitellogenic oocytes of the guppy Poecilia reticulata. J. Exp. Zool. 248, 361-364.

Tse, D. L. Y., Chow, B. K. C., Chan, C. B., Lee, L. T. O., and Cheng, C. H. K. (2000). Molecular cloning and expression studies of a prolactin receptor in goldfish (Carassius auratus). Life Sci. 66, 593-605.

Yamamoto, T., Nakayama, Y., Matsuda, Y., and Abé, S-I. (1998). Cloning and expression of a cDNA encoding a prolactin receptor of the japanese red-bellied newt, Cynops pyrrhogaster. Zool. Sci. 15, 741-747.

Zhou, J. F., Zadworny, D., Guemene, D., and Kuhnlein, U. (1996). Molecular cloning, tissue distribution, and expression of the prolactin receptor during various reproductive states in Meleagris gallopavo. Biol. Reprod. 55, 1081-1090. 